\title{
Influence of Fresh, Composted and Vermicomposted Parthenium hysterphorus and Poultry Droppings on Quality Parametres of Radish
}

\author{
${ }^{2 *}$ VIJAYAKUMARI, B.; ${ }^{1}$ YADAV, R HIRANMAI; ${ }^{1}$ RAJA, A. XAVIER VERGEESE \\ ${ }^{1}$ Department of Biotechnology, Karpagam University, Coimbatore-641021, TamilNadu. \\ ${ }^{2}$ Deparment of Botany, Avinahilingam University, Coimbatore-641043, TamilNadu. \\ (E-mail: mayahiran18@yahoo.com,xavierbt06@yahoo.co.in) \\ "Professor of Botany, 18, Ambross Street, CPS Colony, Kaundampalayam, Coimbatore641030, Tamilnadu (e-mail: \\ bviji_007@yahoo.co.in).
}

\begin{abstract}
A pot culture experiment was carried out to assess the influence of fresh, composted and vermicomposted Parthenium and poultry droppings on the quality parameters of radish like protein, carbohydrates, phenolics, reducing sugar, total soluble sugars and chlorophylls on 45 and 60 DAS (Days After Sowing). The maximum protein content of radish was in $\mathrm{T}_{6}$ on 45 DAS. $\mathrm{T}_{2}$ and $\mathrm{T}_{7}$ had highest carbohydrates content on 45 and 60 DAS respectively. The reducing sugar was more in $T_{11}$. Increased phenol content was found in $T_{14}$ on $45 \mathrm{DAS}$ and $\mathrm{T}_{7}$ on $60 \mathrm{DAS}$.Total soluble sugar was more in $\mathrm{T}_{13}$ on $45 \mathrm{DAS}$ and $\mathrm{T}_{4}$ on $60 \mathrm{DAS}$. The Total chlorophylls was increased in $\mathrm{T}_{1}$ on 45 and $\mathrm{T}_{13}$ on 60 DAS.Chlorophyll "b" was more in $\mathrm{T}_{13}$ on 60 DAS. @ JASEM
\end{abstract}

Globally, the role of vegetable crops has well recognized in solving the problem of food and nutritional security. Urbanisation is causing significant changing in food consumption pattern. Demand of vegetables is increasing fast, which will further increase pressure on future food supply and aggravate the food in security and malnutrition problem. They are rich sources of minerals, vitamins and contain fair amount of carbohydrate and protein. Vegetables with incasing recognition of their value in human diet, are gaining commercial importance (Singh and Kalloo, 2000). Parthenium hysterophorus is an exotic weed accidentally introduced in India and has occupied almost all parts of India. Prolific seeding habit of Parthenium, non-dormancy and extreme lightweight of its seeds armed with pappus are some of the characteristics, which help its extensive spread and establishment. Although Parthenium is a toxic weed it can be used for many purposes such as compost and green leaf manure. (Biradar et al, 2006). Poultry manure is an important by product of poultry industry. Generally poultry industry is distributed around large cities and hence indiscriminate disposal of this huge by product causes source of pollution. The present investigation is an effort to find out the effect of fresh, composted and vermicomposted Parthenium and poultry droppings on the quality parameters of radish (Raphanus sativus Var.Pusa chetki) on 45 and 60 DAS (Days After Sowing)

\section{MATERIALS AND METHODS}

A pot culture experiment was carried out to assess the effect of fresh, composted and vermicomposted Parthenium and poultry droppings on the quality parameters of radish (Raphanus sativus Var.Pusa chetki). The experiment was set up in a completely randomized design with three replications. The dosage were given as per the recommendations of
Tamilnadu Agricultural University, Coimbatore, TamilNadu, India and also based on the nutrient content. The treatment details were

$$
\begin{aligned}
& \mathrm{T}_{0} \quad \text { - Control - Red loamy soil (7 kg) } \\
& \mathrm{T}_{1} \quad \text { - Fresh Parthenium @ } 35 \text { g per pot } \\
& \mathrm{T}_{2} \text { - Composted Parthenium @ 26.25 g per } \\
& \text { pot } \\
& \mathrm{T}_{3} \quad \text { - Composted Parthenium @ 35.0 g per pot } \\
& \mathrm{T}_{4} \text { - Composted Parthenium @ } 43.75 \mathrm{~g} \text { per } \\
& \text { pot } \\
& \mathrm{T}_{5} \quad \text { - Vermicomposted Parthenium @ } 26.25 \mathrm{~g} \\
& \text { per pot } \\
& \text { T } 6 \text { - Vermicomposted Parthenium @35.0 g } \\
& \text { per pot } \\
& \mathrm{T}_{7} \quad \text { - Vermicomposted Parthenium @ } 43.75 \mathrm{~g} \\
& \text { per pot. } \\
& \mathrm{T}_{8} \quad \text { - Poultry droppings @ } 35.0 \text { g per pot } \\
& \mathrm{T}_{9} \quad \text { - Composted poultry droppings @ } 26.25 \mathrm{~g} \\
& \text { per pot } \\
& \mathrm{T}_{10} \quad \text { - Composted poultry droppings @ } 35.0 \mathrm{~g} \\
& \text { per pot } \\
& \mathrm{T}_{11} \quad \text { - Composted poultry droppings @ } 43.75 \mathrm{~g} \\
& \text { per pot } \\
& \mathrm{T}_{12} \text { - Vermicomposted poultry droppings @ } \\
& 26.25 \text { g per pot } \\
& \mathrm{T}_{13} \text { - Vermicomposted poultry droppings @ } \\
& 35.0 \mathrm{~g} \text { per pot } \\
& \mathrm{T}_{14} \text { - Vermicomposted poultry droppings @ } \\
& 43.75 \mathrm{~g} \text { per pot } \\
& \mathrm{T}_{15} \quad \text { - N: P: K (60:30:30 kg/ha) }
\end{aligned}
$$

\section{QUALITY PARAMETERS}

Quality parameters were tested on 45 and 60 DAS (Days After Sowing) using standard procedures. The protein was estimated using the procedure of Lowry et al. (1951), total carbohydrates by Hedge and Hofreiter (1962), total free phenolics by Malick and 
Singh (1980), reducing sugar by Miller (1972), total soluble sugar by Mahadevan and Sridhar (1986) and Chlorophylls following the method of Arnon (1949).

\section{STATISTICAL ANALYSIS OF THE DATA}

The data collected from the different studies were subjected to statistical analysis as per the procedure outlined by Panse and Sukhatme (1978).

\section{RESULT AND DISCUSSION}

The effect of Parthenium and poultry droppings in various treatments on quality parameters of radish were analyzed on 45 and 60 DAS (Table 1). On 45 DAS, the protein content was the highest in $\mathrm{T}_{6}(5.48$ $\mathrm{mg} \mathrm{g}^{-1}$ ) and $\mathrm{T}_{9}\left(3.63 \mathrm{mg} \mathrm{g}^{-1}\right)$ among Parthenium and poultry droppings treatments and the lowest value of $2.94 \mathrm{mg} \mathrm{g}^{-1}$ was recorded in control. The maximum content of total carbohydrates was noticed in $\mathrm{T}_{2}$ $\left(23.78 \mathrm{mg} \mathrm{g}^{-1}\right)$ and $\mathrm{T}_{13}\left(17.26 \mathrm{mg} \mathrm{g}^{-1}\right)$ on $45 \mathrm{DAS}$ among Parthenium and poultry droppings applications. On $60 \mathrm{DAS}, \mathrm{T}_{7}\left(22.44 \mathrm{mg} \mathrm{g}^{-1}\right)$ and $\mathrm{T}_{14}$ (11.78 $\mathrm{mg} \mathrm{g}^{-1}$ ) showed maximum content of total carbohydrates among Parthenium and poultry droppings treatments. The lowest values of $9.98 \mathrm{mg}$ $\mathrm{g}^{-1}$ on 45 DAS and $5.64 \mathrm{mg} \mathrm{g}^{-1}$ on 60 DAS were observed in control. The highest content of reducing sugars was registered in $\mathrm{T}_{6}\left(10.83 \mathrm{mg} \mathrm{g}^{-1}\right)$ and $\mathrm{T}_{4}$ (18.06 $\mathrm{mg} \mathrm{g}^{-1}$ ) on 45 and 60 DAS among Parthenium applied crops. Among poultry droppings applications
$\mathrm{T}_{11}$ registered higher content on $45\left(17.39 \mathrm{mg} \mathrm{g}^{-1}\right)$ and $60\left(18.66 \mathrm{mg} \mathrm{g}^{-1}\right)$ DAS. The lowest content of reducing sugars was seen in control on 45 and 60 (10.16 and $15.99 \mathrm{mg} \mathrm{g}^{-1}$ ) DAS.

The content of total free phenolics on 45 DAS was found to be the highest in $\mathrm{T}_{6}\left(3.68 \mathrm{mg} \mathrm{g}^{-1}\right)$ among Parthenium and $\mathrm{T}_{14}\left(5.58 \mathrm{mg} \mathrm{g}^{-1}\right)$ among poultry droppings applications. On $60 \mathrm{DAS} \mathrm{T}_{7}\left(6.65 \mathrm{mg} \mathrm{g}^{-1}\right)$ registered higher value among Parthenium applications. $\mathrm{T}_{13}\left(3.96 \mathrm{mg} \mathrm{g}^{-1}\right)$ exhibited higher value for total free phenolics among poultry droppings treatments. The lowest level of total free phenolics was seen in $\mathrm{T}_{4}\left(3.18 \mathrm{mg} \mathrm{g}^{-1}\right)$ on $45 \mathrm{DAS}$ and in $\mathrm{T}_{10}$ (2.64 $\mathrm{mg} \mathrm{g}^{-1}$ ) on 60 DAS. Among the various treatments, maximum total soluble sugars were found in $\mathrm{T}_{1}$ (40.86 $\mathrm{mg} \mathrm{g}^{-1}$ ) among Parthenium and in $\mathrm{T}_{13}$ $\left(60.98 \mathrm{mg} \mathrm{g}^{-1}\right)$ among poultry droppings treatments on 45 DAS. On 60 DAS, among Parthenium and poultry droppings applied pots, $\mathrm{T}_{4}\left(61.12 \mathrm{mg} \mathrm{g}^{-1}\right)$ and $\mathrm{T}_{14}\left(41.92 \mathrm{mg} \mathrm{g}^{-1}\right)$ registered higher values. The level of total soluble sugars was minimum in $\mathrm{T}_{8}(18.69 \mathrm{mg}$ $\left.\mathrm{g}^{-1}\right)$ on 45 DAS and in control (16.74 $\left.\mathrm{mg} \mathrm{g}^{-1}\right)$ on 60 DAS. The chlorophylls content of radish (Raphanus sativus) leaves analyzed are presented in Table 2 . On 60 DAS, significantly higher chlorophyll b content was observed in $\mathrm{T}_{5}\left(0.18 \mathrm{mg} \mathrm{g}^{-1}\right)$ among Parthenium treated plants and in $T_{13}\left(0.37 \mathrm{mg} \mathrm{g}^{-1}\right)$ among poultry droppings treated plants, while the lower content was seen in $\mathrm{T}_{4}\left(0.13 \mathrm{mg} \mathrm{g}^{-1}\right)$.

Table 1: Impact of fresh, composted, vermicomposted Parthenium and poultry droppings on quality parameters ( $\mathrm{mg} \mathrm{g}^{-1}$ ) of Raphanus

\begin{tabular}{|c|c|c|c|c|c|c|c|c|c|c|}
\hline \multirow[t]{2}{*}{ Treatments } & \multirow{2}{*}{$\begin{array}{l}\text { Protein } \\
45 \mathrm{DAS}\end{array}$} & \multirow[b]{2}{*}{$60 \mathrm{DAS}$} & \multicolumn{2}{|c|}{ Total carbohydrates } & \multicolumn{2}{|c|}{ Reducing sugars } & \multicolumn{2}{|c|}{ Total free phenolics } & \multicolumn{2}{|c|}{ Total soluble sugars } \\
\hline & & & 45 DAS & 60 DAS & 45 DAS & 60 DAS & 45 DAS & 60 DAS & 45 DAS & $60 \mathrm{DAS}$ \\
\hline $\mathrm{T}_{0}$ & 2.94 & 3.92 & 9.98 & 5.64 & 10.16 & 15.99 & 3.28 & 4.89 & 20.19 & 16.74 \\
\hline $\mathrm{T}_{1}$ & 4.60 & 5.22 & 12.81 & 11.63 & 10.60 & 17.12 & 3.36 & 6.56 & 40.86 & 37.03 \\
\hline $\mathrm{T}_{2}$ & 4.53 & 6.40 & 23.78 & 11.48 & 10.52 & 16.94 & 3.47 & 3.69 & 38.39 & 30.20 \\
\hline $\mathrm{T}_{3}$ & 4.36 & 4.96 & 11.54 & 14.00 & 10.45 & 17.43 & 3.25 & 3.38 & 27.50 & 22.94 \\
\hline $\mathrm{T}_{4}$ & 4.60 & 6.02 & 10.74 & 15.26 & 10.44 & 18.06 & 3.18 & 4.45 & 38.45 & 61.12 \\
\hline $\mathrm{T}_{5}$ & 4.41 & 4.90 & 17.77 & 13.93 & 10.61 & 17.03 & 3.25 & 4.73 & 25.00 & 52.45 \\
\hline $\mathrm{T}_{6}$ & 5.48 & 5.47 & 16.29 & 19.88 & 10.83 & 16.88 & 3.68 & 5.07 & 40.27 & 44.27 \\
\hline $\mathrm{T}_{7}$ & 5.30 & 5.37 & 17.99 & 22.44 & 10.50 & 16.56 & 3.23 & 6.65 & 26.19 & 31.57 \\
\hline $\mathrm{T}_{8}$ & 3.41 & 5.08 & 11.49 & 7.88 & 12.42 & 17.35 & 3.70 & 3.04 & 18.69 & 27.88 \\
\hline $\mathrm{T}_{9}$ & 3.63 & 5.37 & 12.34 & 6.42 & 16.74 & 17.64 & 4.46 & 2.84 & 30.95 & 20.26 \\
\hline $\mathrm{T}_{10}$ & 3.55 & 4.85 & 16.99 & 9.94 & 12.04 & 17.64 & 4.06 & 2.64 & 27.42 & 24.43 \\
\hline $\mathrm{T}_{11}$ & 3.24 & 4.37 & 11.31 & 5.93 & 17.39 & 18.66 & 3.55 & 3.86 & 43.72 & 26.60 \\
\hline $\mathrm{T}_{12}$ & 3.47 & 4.97 & 16.99 & 6.60 & 15.94 & 17.90 & 4.05 & 3.55 & 27.96 & 21.60 \\
\hline $\mathrm{T}_{13}$ & 3.42 & 5.02 & 17.26 & 6.05 & 13.75 & 18.29 & 4.69 & 3.96 & 60.98 & 28.26 \\
\hline $\mathrm{T}_{14}$ & 3.34 & 5.53 & 16.51 & 11.78 & 14.31 & 18.12 & 5.58 & 3.79 & 27.64 & 41.92 \\
\hline $\mathrm{T}_{15}$ & 3.25 & 4.51 & 11.91 & 8.62 & 11.53 & 18.16 & 5.11 & 3.82 & 33.09 & 26.93 \\
\hline SEd & 0.41 & NS & 2.64 & 1.47 & 0.57 & 0.67 & 0.58 & 0.50 & 3.07 & 3.44 \\
\hline $\mathrm{CD}(5 \%)$ & $0.84 * *$ & & $5.39 * *$ & $3.01 * *$ & $1.17 * *$ & $1.37 *$ & $1.18^{* *}$ & $1.03 * *$ & $6.28^{* *}$ & $7.03 * *$ \\
\hline
\end{tabular}

SEd - Standard Error Deviation; CD - Critical Difference; DAS - Days After Sowing

* Corresponding author: ${ }^{2 *}$ Vijayakumari, B. 
Table 2: Impact of fresh, composted and vermicomposted Parthenium and poultry droppings on chlorophylls content (mg g ${ }^{-1}$ ) of Raphanus sativus

\begin{tabular}{lllllll} 
Treatments & \multicolumn{2}{l}{ Chlorophyll a } & \multicolumn{2}{l}{ Chlorophyll b } & \multicolumn{2}{l}{ Total chlorophylls } \\
& 45 DAS & $60 \mathrm{DAS}$ & $45 \mathrm{DAS}$ & $60 \mathrm{DAS}$ & $45 \mathrm{DAS}$ & $60 \mathrm{DAS}$ \\
$\mathrm{T}_{0}$ & 1.00 & 0.77 & 0.33 & 0.17 & 1.18 & 0.94 \\
$\mathrm{~T}_{1}$ & 1.07 & 0.84 & 0.32 & 0.15 & 1.40 & 0.99 \\
$\mathrm{~T}_{2}$ & 0.69 & 0.86 & 0.42 & 0.16 & 1.35 & 1.02 \\
$\mathrm{~T}_{3}$ & 0.85 & 0.80 & 0.21 & 0.15 & 1.05 & 0.95 \\
$\mathrm{~T}_{4}$ & 0.92 & 0.78 & 0.26 & 0.13 & 1.18 & 0.91 \\
$\mathrm{~T}_{5}$ & 1.06 & 0.82 & 0.32 & 0.18 & 1.37 & 1.04 \\
$\mathrm{~T}_{6}$ & 0.99 & 0.92 & 0.23 & 0.16 & 1.21 & 0.96 \\
$\mathrm{~T}_{7}$ & 0.97 & 0.73 & 0.18 & 0.16 & 1.14 & 0.89 \\
$\mathrm{~T}_{8}$ & 0.63 & 0.87 & 0.19 & 0.32 & 0.85 & 1.19 \\
$\mathrm{~T}_{9}$ & 0.80 & 0.78 & 0.24 & 0.17 & 0.91 & 0.97 \\
$\mathrm{~T}_{10}$ & 0.74 & 0.99 & 0.18 & 0.31 & 0.92 & 1.29 \\
$\mathrm{~T}_{11}$ & 0.67 & 0.88 & 0.25 & 0.31 & 0.91 & 1.19 \\
$\mathrm{~T}_{12}$ & 0.66 & 0.76 & 0.21 & 0.32 & 0.87 & 1.08 \\
$\mathrm{~T}_{13}$ & 0.69 & 0.94 & 0.22 & 0.37 & 0.91 & 1.31 \\
$\mathrm{~T}_{14}$ & 0.67 & 0.91 & 0.20 & 0.34 & 0.87 & 1.22 \\
$\mathrm{~T}_{15}$ & 0.62 & 0.69 & 0.21 & 0.30 & 0.83 & 0.84 \\
$\mathrm{SEd}$ & NS & NS & NS & 0.04 & 0.18 & 0.12 \\
$\mathrm{CD}(5 \%)$ & & & & 0.08 & 0.36 & 0.23 \\
\hline $\mathrm{SEd}$ - Standard Error Deviation; CD - Critical Difference; DAS - Days After Sowing
\end{tabular}

The total chlorophylls was significantly high in $T_{1}$ $\left(1.40 \mathrm{mg} \mathrm{g}^{-1}\right)$ and $\mathrm{T}_{10}\left(0.92 \mathrm{mg} \mathrm{g}^{-1}\right)$ among Parthenium and poultry droppings applied plants on 45 DAS. On 60 DAS, same was seen in $\mathrm{T}_{5}(1.04 \mathrm{mg}$ $\left.\mathrm{g}^{-1}\right)$ among Parthenium and $\mathrm{T}_{13}\left(1.31 \mathrm{mg} \mathrm{g}^{-1}\right)$ among poultry droppings treatments. Very low levels of total chlorophylls were observed in NPK $(0.83$ and 0.84 $\mathrm{mg} \mathrm{g}^{-1}$ ) on 45 and 60 DAS. Jadhav et al., (1988) have reported increased crude protein content in the leaves of mulberry by application of vermicompost. Recommended NPK+FYM with earthworms are beneficial in respect of reducing sugar, total soluble sugar, acidity ratio in sapota fruits (Gawande et al., 1998). Chlorophyll, Nitrogen and protein content was found to be high in the leaves of vermicompost treated mulberry (Reddy et al., 2003). This clearly indicates that vermicompost was rich in NPK, micronutrients and enzymes. The present study of many beneficial microorganisms and enzyme influenced the $\mathrm{N}$ and protein synthesis, which in turn improves the leaf quality. Application of poultry manure + RDF recorded highest LAI,photosynthetic rate and grain yield with better partitioning efficiency. The next best treatment was RDF in combination with Parthenium compost which had on par yield with poultry manure. Composts prepared from weed species before flowering stage had more beneficial effects than the composts prepared at later stages because of higher nutrients content(Channappagoudar et al.,2008). Vermicomposts had a positive effect on the rice quality $(\mathrm{N}, \mathrm{P}$, and $\mathrm{K}$ plant contents, pigments, and leaf soluble carbohydrate concentrations). The increase in soil biological properties produced an increase in the plant nutrition, which increased rice quality and yield. The application of cow dung increased the grain protein concentration, the grain starch concentration ,the percentage of full grains , and the rice yield,compared with the green forage amended soils. These results suggest that the chemical composition of the two vermicomposts influenced the soil biological properties, and therefore in the rice yield parameters. For both vermicomposts, the application of cow dung originated an increase in the soil biological properties and also in the rice yield parameters (Tejada and González, 2009).

\section{REFERENCES}

Arnon, DE (1949). Copper enzymes in isolated chloroplasts. Pl. Physiol., 24: 1-5.

Biradar. DP, Shivakumar. K S, Prakash, SS, Pujar T (2006). Bionutrient potentiality of Parthenium hysterophours and its utility of green manure in rice ecosystem. Karnataka J .Agric. Sci, 19: 256263.

Gawande, SS, Jiotode, Turkhede. AB (1998). Effect of organic and inorganic fertilizers on yield and quality of sapota. J. Soils and Crops, 8: 58-60.

Hedge, JE, Hofreiter, BT (1962). In: Carbohydrate chemistry. R.L. Whistler and J.N. Be Miller (eds.), Academic Press, New York..

Jadhav, SN, Patil, GM, Kulkarni, BS Shivaprasad. M (1998). Influence of vermicompost, inorganic fertilizer and their combinations on the nutritive value of M-5 mulberry. Adv. Agric. Res. India, 10: 133-139.

* Corresponding author: ${ }^{2 *}$ Vijayakumari, B. 
Lowry, OH, Rosenbrough, NJ, Farr AL, Randall. RJ (1951). Protein measurement with folin phenol reagent. J. Biol. Chem., 193: 267-275.

Mahadevan, A, Sridhar, R. (1986). Methods in physiological plant pathology. Sivakami Publications, Madras.

Malick, CP, Singh. MB (1980). In: Plant enzymology and histo enzymology, Kalyani Publishers, New Delhi.

Miller, GL. (1972). Anal Chem., 31: 426 (cited by Sadasivam, S. and A. Manickam, 1992. In: Biochemical Methods, Wiley Eastern Ltd., New Delhi.
Panse, VG, Sukhatme. PV (1978). Statistical methods for agricultural workers, ICAR, New Delhi.

Singh, PP, Kaushal,PK. 1975. Effect of nitrogen and phosphorus rates and spacings on the seed yield and yield attributing characters of sunflower (Helianthus annuus L.). Mysore J. Agric. Sci., 9: 660-663.

Tejada M. and JL. González 2009 Application of Two Vermicomposts on a Rice Crop: Effects on Soil Biological Properties and Rice Quality and Yield Agron J 101:336-344 